\title{
Influence of seasonality, salinity and temperature on catch trend of Penaeus indicus H. Milne-Edwards, 1837 in a coastal lagoon, India
}

\author{
R. K. RAMAN, V. R. SURESH, S. K. MOHANTY*, K. S. BHATTA*, S. K. KARNA, \\ B. P. MOHANTY AND B. K. DAS \\ ICAR-Central Inland Fisheries Research Institute, Barrackpore, Kolkata - 700 120, India \\ ${ }^{*}$ Chilika Development Authority, C-11, BJB Nagar, Bhubaneswar - 751 014, Odisha, India \\ e-mail: basantakumard@gmail.com
}

\begin{abstract}
The catch pattern of Penaeus indicus H. Milne-Edwards, 1837 in coastal lagoons is influenced by seasonal changes in physicochemical parameters of the lagoon ecosystem. In this study the effects of seasonality, salinity and water temperature of lagoon on P. indicus catch were analysed using Structural Time Series Model (STSM) and ARIMAX (Auto Regressive Integrated Moving Average with explanatory variables) modeling approach using monthly time series catch, salinity and water temperature data of the Chilika Lagoon (a Ramsar site) in India for the period from 2001 to 2015. Results showed a significant $(\mathrm{p}<0.05)$ increasing stochastic upward trend and two seasonal cycles for $P$. indicus catch in the lagoon. Salinity was found to have significant positive influence $(\mathrm{p}<0.05)$ and temperature to have insignificant positive influence on $P$. indicus catch in the lagoon.
\end{abstract}

Keywords: ARIMAX, Chilika, Cycle, Shellfish, STSM, Trend

\section{Introduction}

Coastal lagoons which form confluence of fresh and marine water serve as highly productive areas for many dependent estuarine species (Elliot and Hemingway, 2002). Environmental and water quality parameters such as water temperature and salinity of coastal lagoons are found to affect fish distribution (Blaber and Blaber, 1980; Cyrus, 1996; Marshall and Elliot, 1998; Pombo et al., 2005; Bruno et al., 2013). Coastal lagoon water bodies serve as grounds for biological and reproductive cycles of several marine species (Galvan-pina et al., 2003) and exhibit mainly physical variation in salinity and temperature (Isla, 1995). The fish community changes with changes in temperature and salinity in the estuarine systems (Palwan et al., 2010).

The Chilika Lake is the largest brackishwater lagoon in Asia, a Ramsar site of international importance situated in India. It is a hotspot of biodiversity which harbours more than 29 species of shrimps (Mohapatra et al., 2015). The Indian white shrimp, Penaeus indicus H. Milne Edwards, 1837 forms the most important penaeid shrimp fishery in India (Mohamed, 1969) with high commercial value, particularly as one of the most sought for exportable seafood items. The species completes its life cycle in estuarine and marine habitats (Mohamed, 1969; FAO, 1980). Restoration of the fragile ecosystem of Chilika Lagoon through hydrological intervention by opening a new lake mouth in the outer channel in September 2000 witnessed spectacular enhancement of fisheries in general and shrimp fisheries in particular (Mohapatra et al., 2007; Mohanty et al., 2008). The fishery of this species takes a dominant place among penaeids in Chilika Lake though it shows extreme fluctuations from year to year (Rao, 1967; Subrahmanyam, 1967; Jhingran and Natarajan, 1969). The average annual yield of $P$. indicus from Chilika Lake during the last 15 years of post-restoration period (2001-02 to 2015-16) fluctuated between 318 and $1964 \mathrm{t}$ showing high degree of fluctuation and contributed $28.46 \%$ to the total yield of penaeid shrimps. The average annual yield registered $476.9 \%$ increase in comparison to the average annual yield during the 15 years of prerestoration period. Thus annual yield of $P$. indicus in Chilika Lake shows a clear trend of fluctuation.

Monthly time series of $P$. indicus catch data of Chilika is influenced by a number of unobserved components such as trend, cycle, seasonality and irregularity, which are not that easy to understand directly by visualising the long term time series catch data. Time series analysis produces a model defining the stochastic processes, which governs periodic trends over time. Box and Jenkins (1976) described the well known Auto-Regressive Integrated Moving Average (ARIMA) time series forecasting model. ARIMA model is used for short term fisheries forecasting (Stergiou, 1991). ARIMA model with exogenous variable 
is known as ARIMAX model, which is capable of identifying the underlying patterns in time series data and to quantify the impact of environmental influence (Bruce et al., 2013). Structural Time Series Model (STSM) (Harvey, 1996) is an alternative of ARIMA model. STSM analyses the univariate time series data using an unobserved components model (UCM). Freeman and Kirkwood (1995) estimated stock of biomass and recruitment from catch effort data using STSM model. Trend analysis was performed on fisheries data of Nephrops norvegicus in European waters (Zuur et al., 2003) of southern Portugal to explore possible environmental variables (Erzini et al., 2005) and also of Loligo sp. in the North-east Atlantic (Zuur and Pierce, 2004). Works have been carried out to correlate the influence of water quality parameters on fish assemblage and distribution in the estuaries using multivariate dimension reduction techniques such as principal component analysis (PCA), canonical correspondence analysis (CCA) and non-metric multidimensional scaling (nMDS) (Blaber and Blaber, 1980; Marshall and Elliot, 1998; Selleslagh and Amara, 2008; Bruno et al., 2013).

Very little work has been conducted to find out the catch trend and seasonal (cyclic) catch behaviour of fish species in general and shrimps in particular, as well as the influence of salinity and temperature on their catch trend using statistical time series modelling approach. The aim of this study was to get the information on (i) catch trend of $P$. indicus on which large number of fishers around Chilika Lagoon depend for their livelihood and (ii) the influence of salinity and water temperature on P. indicus catch in the coastal lagoon, which is a Ramsar site in India. Catch prediction is important for appropriate planning and designing of the national fishery development plan and to secure the livelihood of the fishers living in/and around the water bodies. This two way approach would provide way to assess the potential of $P$. indicus fishery for sustainable exploitation as well as for decision making and future planning.

\section{Materials and methods}

\section{Study area}

Chilika Lagoon (Fig. 1) lying between latitudes $19^{\circ}$ $20^{\prime} 13.06^{\prime \prime} \mathrm{N}$ and $19^{\circ} 54^{\prime} 47.02^{\prime \prime} \mathrm{N}$ and longitudes $085^{\circ}$ $06^{\prime} 49.15^{\prime \prime} \mathrm{E}$ and $085^{\circ} 35^{\prime} 32.87^{\prime \prime} \mathrm{E}$ is the second largest lake in the world with estuarine character. The water spread area fluctuates between a monsoon maximum of $1165 \mathrm{~km}^{2}$ and dry season minimum of $906 \mathrm{~km}^{2}$ (World Bank, 2005; Mohapatra et al., 2007). The lake is influenced by three hydrologic sub-systems viz., the Mahanadi distributaries, the rivers draining into the lake from the western catchment and influx of seawater from Bay of Bengal. Depending on the salinity gradient and depth profile, the lake is divided into four ecological sectors namely, northern, central, southern and outer channel sectors (Jhingran, 1963). The lake is connected with the sea by a long outer channel and the $14 \mathrm{~km}$ long Palur canal in the southern part. Chilika Lake is an assemblage of marine, brackish and freshwater ecosystems which characterised the lake fishery with fish and shellfish fauna from marine, brackish and freshwater environments. The rich fish and shellfish fisheries of the lake support the livelihood of more than 0.2 million local

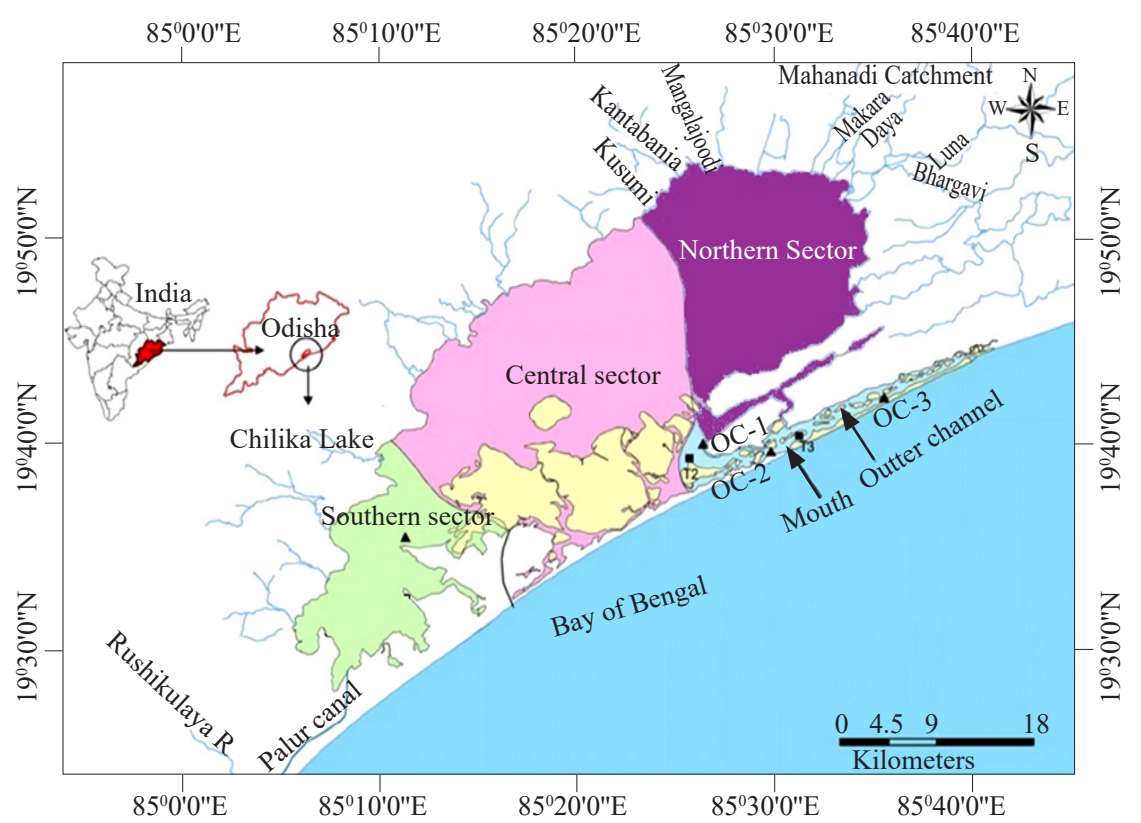

Fig. 1. Map of Chilika Lagoon, Odisha, India 
fishers (Mohanty et al., 2015). Opening of the new lake mouth as a part of hydrological intervention for ecorestoration of the lake in September 2000 witnessed an immediate positive impact with spectacular enhancement in fisheries with significant contribution of shrimp fisheries to the commercial landings (Mohapatra et al., 2007).

\section{Source of data}

In this study, monthly estimated time series catch data of $P$. indicus of Chilika Lagoon for the period from April 2001 to March 2015 was collected from the Chilika Development Authority (CDA), Bhubaneswar, Odisha, India. A random sampling design with landing centre approach (Gupta et al., 1991), modified for site specific conditions (Jhingran and Natarajan, 1969) was followed for catch estimation. Monthly water quality parameters of the lagoon viz., salinity (ppt) and water temperature $\left({ }^{\circ} \mathrm{C}\right)$ for the study period from April 2001 to March 2015 were also collected from CDA.

\section{Methodology for model development}

The unobserved components of response series was decomposed by Structural Time Series Model (STSM) for monthly observations which comprised trend, cycle, seasonal and irregular components given by Harvey (1989):

$$
\mathrm{y}_{\mathrm{t}}=\mu_{\mathrm{t}}+\Psi_{\mathrm{t}}+\gamma_{\mathrm{t}}+\varepsilon_{\mathrm{t}}, \mathrm{t}=1, \ldots, \mathrm{T}
$$

If, trend and cyclical components are present, then (1) can be written as:

$$
\mathrm{y}_{\mathrm{t}}=\mu_{\mathrm{t}}+\Psi_{\mathrm{t}}+\varepsilon_{\mathrm{t}}, \mathrm{t}=1, \ldots, \mathrm{T}
$$

since, $\mu_{\mathrm{t}}$ depends over time; let,

$$
\mu_{\mathrm{t}=} \mu_{\mathrm{t}-1}+\beta_{\mathrm{t}-1}+\eta_{\mathrm{t}} \text {, }
$$

where, $\beta_{\mathrm{t}}=\beta_{\mathrm{t}-1}+\varsigma_{\mathrm{t}} \mathrm{t}=-1,0,1$

Here, $\mu_{t}$ is the trend, $\Psi t$ is the cycle, $\gamma_{t}$ is the seasonal component and $\varepsilon_{t}$ is the irregular component. All four components are stochastic and the disturbances driving them are mutually uncorrelated and follow $\mathrm{N}\left(0, \sigma_{\varepsilon}^{2}\right), \mathrm{N}(0$, $\left.\sigma_{\eta}^{2}\right)$ and $N\left(0, \sigma_{\varsigma}^{2}\right)$ distributions. The trend, season and cycle are all derived from deterministic functions of time and reduce to these functions as limiting cases. The irregular component is white noise.

Let $\Psi_{\mathrm{t}}$ be a cyclical function of time with frequency $\lambda_{c}$, which is measured in radians. The period of the cycle, which is the time taken to go through its complete sequence of values, is $\frac{2 \pi}{\lambda}$. A cycle can be expressed as a mixture of sine and cosine waves, depending on two parameters, $\alpha$ and $\beta$, thus:

$$
\Psi_{t}=\alpha \cos \lambda_{c} t+\beta \sin \lambda_{c} t
$$

where, $\left(\alpha^{2}+\beta^{2}\right)^{\frac{1}{2}}$ is the amplitude and $\tan ^{-1}\left(\frac{\beta}{\alpha}\right)$ is the phase. Like the linear trend, the cycle can be built up recursively, leading to the stochastic model:

$$
\left[\begin{array}{l}
\Psi \mathrm{t} \\
\Psi_{\mathrm{t}}^{*}
\end{array}\right]=\rho\left[\begin{array}{l}
\cos _{\lambda c} \sin _{\lambda c} \\
-\sin _{\lambda c} \cos _{\lambda c}
\end{array}\right]\left(\begin{array}{c}
\Psi_{\mathrm{t}-1} \\
\Psi_{\mathrm{t}-1}^{*}
\end{array}\right)+\left(\begin{array}{l}
\mathrm{k}_{\mathrm{t}} \\
\mathrm{k}_{\mathrm{t}}^{*}
\end{array}\right)
$$

where, $\mathrm{k}_{\mathrm{t}}$ and $\mathrm{k}_{\mathrm{t}}^{*}$ are mutually uncorrelated with a common variance, $\sigma_{\mathrm{k}}^{2}$ and $\rho$ is a damping factor, such that $0 \leq \rho \geq 1$. The model is stationary if $\rho$ is strictly less than one and if $\lambda_{\mathrm{c}}$ is equal to 0 or $\pi$ it reduced to a first-order auto regressive process. The developed model parameters are estimated by Kalman filter (Meinhold and Singpurwalla, 1983) recursive procedure.

Further, ARIMAX model is developed using well known model by Box-Jenkins (1976), Auto-Regressive Integrated Moving Average (ARIMA) with external regressors i.e., salinity and temperature associated with the time series catch data. SARIMA model included ARIMA with seasonal parameters. It can be written as: SARIMA $(p, d, q)(P, D, Q) \mathrm{s}$, where the first term is non-seasonal component and the second is seasonal component. Here, $p$, $d$ and $q$ respectively represent the autoregressive order (AR), difference order to make data stationary and order of moving average (MA) and $\mathrm{S}$ represents seasonality (periods) with $P, D, Q$ seasonal order AR, difference order and MA terms.

ARIMA model is expressed as:

$$
\mathrm{W}_{t}=\mu+\frac{\theta(\mathrm{B})}{\phi(\mathrm{B})} a_{t,}
$$

where, $t$ : indexes time, $\mathrm{W}_{\mathrm{t}}$ : is the response series or difference of the response series, $\mu$ is the mean, $\mathrm{B}$ is the backshift operator, that is $\mathrm{BX}_{\mathrm{t}=} \mathrm{X}_{\mathrm{t}-1,} \phi(\mathrm{B})$ is the autoregressive operator, represented as polynomial in the backshift operator : $\phi(\mathrm{B})=1-\phi_{1} \mathrm{~B}-\ldots-\phi p \mathrm{~B}^{p}, \theta(\mathrm{B})$ is the moving-average operator, represented as polynomial in the backshift operator : $\theta(\mathrm{B})=1-\theta_{l} \mathrm{~B}-\ldots-\theta_{q} \mathrm{~B}^{q}$ and $a_{\mathrm{t}}$ is the independent disturbance, also called the random error.

The general ARIMA model with predictor series known as ARIMAX model is written as:

$$
W_{t}=\mu+\sum i \frac{\omega \mathrm{i}}{\delta \mathrm{i}} B^{k i} X_{i t}^{\prime}+\frac{\theta(\mathrm{B})}{\phi(\mathrm{B})} a_{t,}
$$

where, $X_{i t}$ is the input series or difference of the input series at time $t . k i$ is the pure time delay for the effect of $i^{\text {th }}$ input series. $\omega \mathrm{i}(\mathrm{B})$ is the numerator polynomial of transfer function for $i^{\text {th }}$ input series and $\delta \mathrm{i}(\mathrm{B})$ is the denominator polynomial of transfer function for $i^{\text {th }}$ input series. The popular minimisation criterion (smaller is better), proposed by Akaike (1979), AIC criterion and the Schwartz-Bayesian Information Criterion (SBC) proposed by Schwartz (1978), were used for best fit model selection. The criterion is AIC $=-2 \log \mathrm{L}+2 \mathrm{n}$, where $\mathrm{L}$ 
is the likelihood function expressed as one step ahead prediction error and $\mathrm{n}$ is the number of hyper parameters estimated from the model and the SBC criterion is given by $\mathrm{SBC}=-2 \log \mathrm{L}+\mathrm{n} \log \mathrm{T}$, where $\mathrm{T}$ is the total number of observations. The goodness of fit statistics i.e., R-Square $\left(\mathrm{R}^{2}\right)$, Adjusted-R-Square $\left(\mathrm{R}^{2}\right)$ and Mean Absolute Percent Error (MAPE) were also taken for accessing the developed model.

At first, the data sets were divided into two parts, training and testing data sets for model development followed by validation of the best model. The catch data for the period 2001 to 2012 was used for training data sets and rest of the data for the period from 2013 to 2015 was used for testing data. Only catch data was used for cyclic and trend analysis by STSM modelling approach. Further, catch data with salinity and temperature was used for the ARIMAX model development. Finally, best model was selected using model selection criteria. The SAS 9.3 software was used for data analysis.

\section{Results}

Monthly average catch of $P$. indicus in the lagoon was observed to be $91.53 \pm 122.96 \mathrm{t}$ for the period from 2001 to 2015 . Therefore a large variation in monthly catch was observed in the lagoon (Fig. 2). Seasonal (monthly) variation in salinity and temperature were also observed (Fig. 3). The mean temperature in the lagoon during the study period was found to be $28.65 \pm 2.74^{\circ} \mathrm{C}$ and average salinity was $11.53 \pm 6.13$ ppt (Fig. 3).

The catch cycle and trend was analysed by STSM approach for $P$. indicus following equation (2) i.e., Catch $=$ Trend + Cycle + Irregular. Trend and cycle components were estimated in the model by the Kalman filter using monthly time series data. Parameter estimates for trend and cycles are presented in Table 1. Two catch cycles were estimated as cycle 1 and 2 . Both the cycles showed stationary since damping factor was found less than one. The catch cycle period for cycle 1 is of 12.03 months (one year approximate) (Fig. 4) and cycle 2 is of 5.77 months (half year approximately) (Fig. 5). Both cycles were significant $(p<0.001)$. It is evident that, the cycle formation as building blocks constructs more complex periodic pattern. The superimposing cycles of different periods and amplitudes produced complex periodic pattern. Specially, the sums of cycles can be created by the seasonal patterns, general periodic patterns with integer periods. Level and slope components variances were found significant $(\mathrm{p}<0.001)$ indicating significant stochastic upward trend for $P$. indicus catch (Fig. 6). The significant stochastic trend means the trend explains most of the model's variation that leads to high degree of flexibility causing difficulty in forecasting the future movement. That means the smooth trend will allow the cycle to explain most of model's variation. Here the developed model has adequate accuracy measures for goodness of fit i.e., $\mathrm{R}^{2}=0.65$, showed good fitting (Table 1). Other fit statistics are also shown in Table 1. The significant upward trend in $P$. indicus catch indicated increase in catch in near future, provided the present environmental conditions of the lagoon are maintained.

ARIMAX model was fitted on $P$. indicus catch, salinity and water temperature data of the Chilika Lagoon using well-known model by Box-Jenkins (1976). The ARIMAX model showed influence of salinity and temperature on $P$. indicus catch in Chilika (Table 2). The ARIMAX model, ARIMA $(2,0,0)(1,0,0) \mathrm{s}+$ salinity

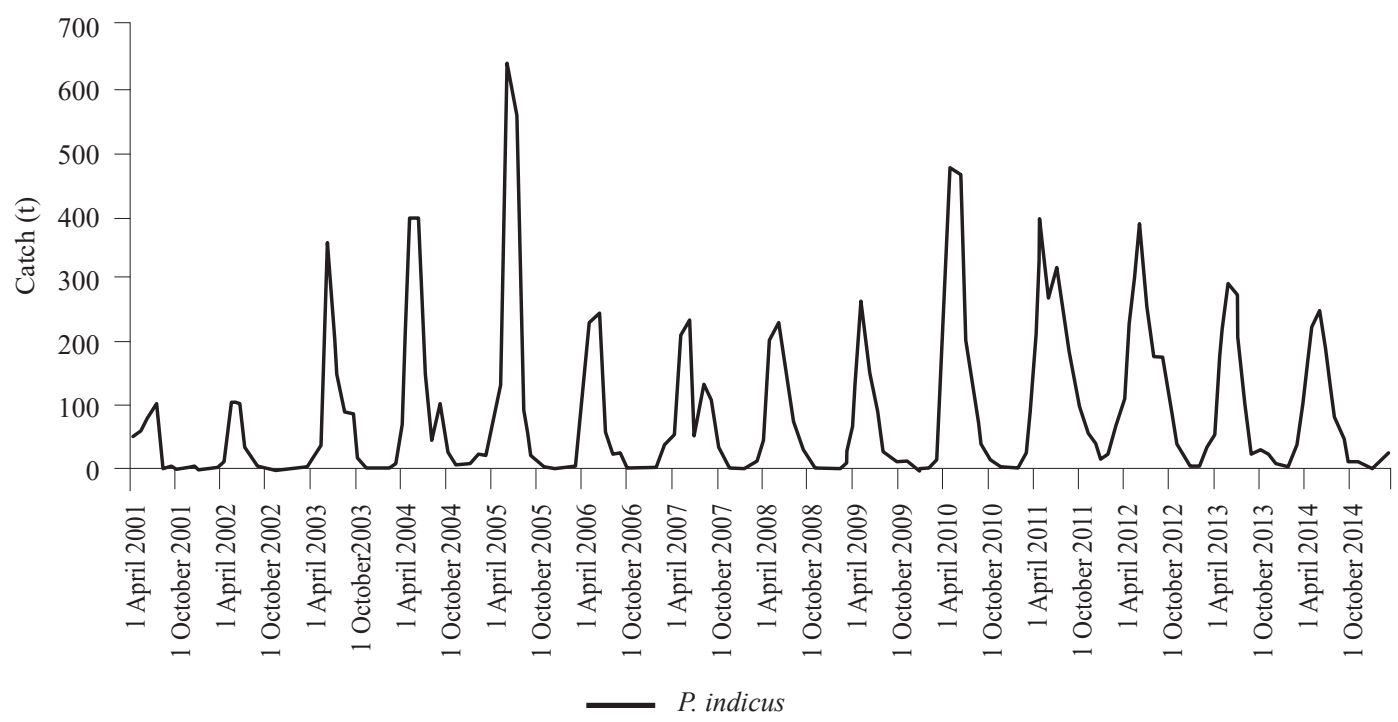

Fig. 2. Monthly catch of $P$. indicus from Chilika Lagoon during April 2001 to March 2015 


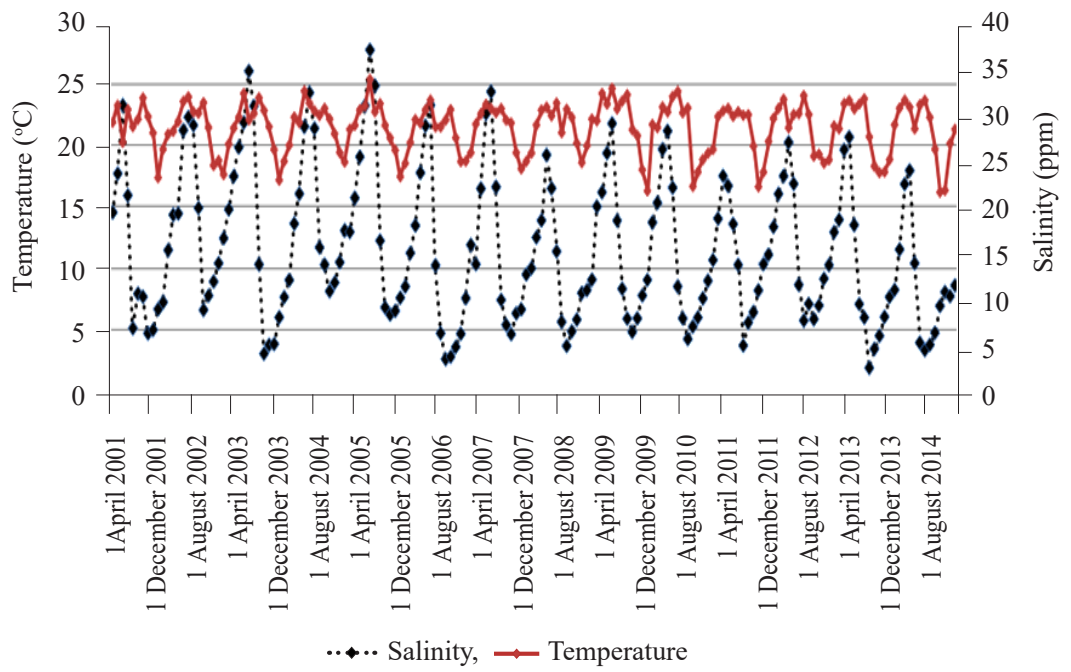

Fig. 3. Monthly variation in salinity (ppm) and temperature $\left({ }^{\circ} \mathrm{C}\right)$ of Chilika Lagoon for the period April 2001 to March 2015

Table 1. Final estimate of free parameters (Irregular, Cycle 1 and Cycle 2) and significance of parameters with fit statistics [AIC, SBC, $\mathrm{R}$ square $\left(\mathrm{R}^{2}\right)$, Adjusted $\mathrm{R}^{2}$ and MAPE] of $P$. indicus catch using STSM approach in Chilika for the period 2001-2005

\begin{tabular}{|c|c|c|c|c|c|}
\hline \multirow{3}{*}{$\begin{array}{l}\text { Component } \\
\text { Irregular }\end{array}$} & \multirow{3}{*}{$\begin{array}{l}\text { Parameter } \\
\text { Error variance }\end{array}$} & \multirow{3}{*}{$\begin{array}{l}\text { Esr. } \\
0.0000615\end{array}$} & \multicolumn{3}{|l|}{ Approx } \\
\hline & & & \multirow{2}{*}{$\frac{\operatorname{Pr}>|t|}{0.083}$} & \multicolumn{2}{|c|}{ Fit Statistics } \\
\hline & & & & AIC & 1863.2 \\
\hline Cycle 1 & Damping factor & 0.99 & $<.0001$ & SBC & 1894 \\
\hline Cycle 1 & Period & 12.03 & $<.0001$ & $\mathrm{R}$ square $\left(\mathrm{R}^{2}\right)$ & 0.65 \\
\hline Cycle 1 & Error variance & 106.19 & 0.12 & Adjusted $\mathrm{R}^{2}$ & 0.63 \\
\hline Cycle 2 & Damping factor & 0.73 & $<.0001$ & MAPE & 377.05 \\
\hline Cycle 2 & Period & 5.58 & $<.0001$ & & \\
\hline Cycle 2 & Error variance & 2577.98 & $<.0001$ & & \\
\hline
\end{tabular}

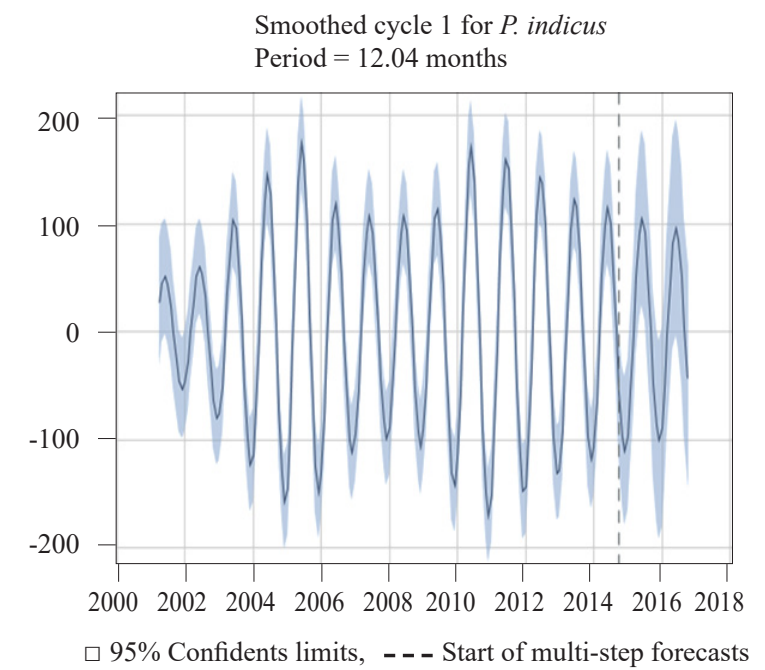

Fig. 4. Smoothed stationary cycle 1 (12 months cycle) for monthly catch of $P$. indicus from Chilika Lagoon during 2001-15

+ temperature found best fitted for $P$. indicus catch. The fit statistics i.e., R-square (0.75) is maximum and AIC (1364.9) and mean absolute percent error (379.79) were

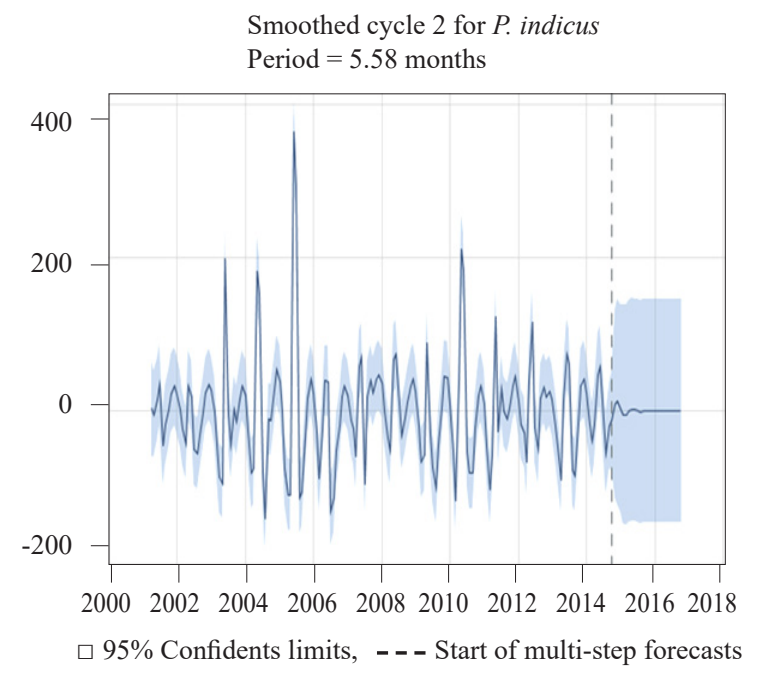

Fig. 5. Smoothed stationary cycle 2 (6 months cycle) for $P$. indicus monthly catch of Chilika Lagoon during 2001-15

observed to be minimum for the best fitted ARIMAX model. The model for $P$. indicus catch showed that salinity has significant positive influence (3.64, $\mathrm{p}=0.03$ ) on the catch. Temperature $(0.74, \mathrm{p}=0.76)$ also showed positive 


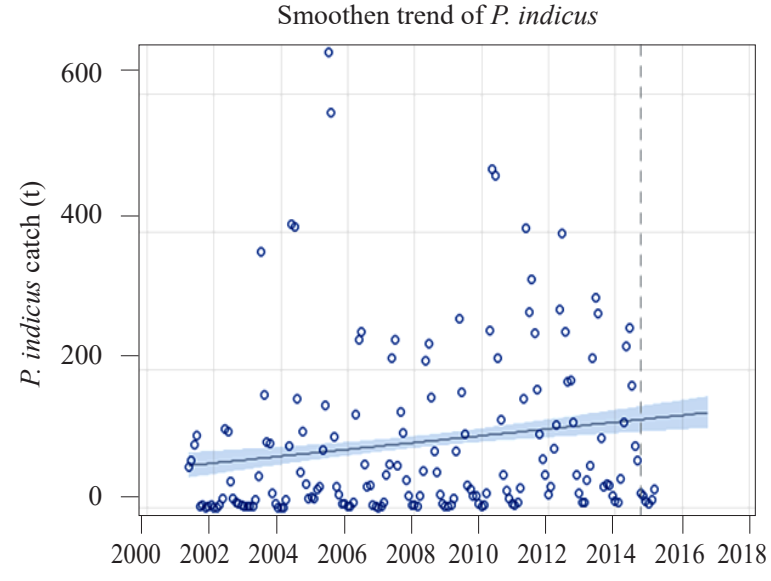

○ Actual, - - - Start of multi-step forecasts, $\square 95 \%$ Confidents limits

Fig. 6. Smoothed increasing upward trend for $P$. Indicus monthly catch of Chilika Lagoon during 2001-15

influence but was statistically insignificant. Annual seasonality $(0.44, \mathrm{p}<0.001)$ was found to be positive and significant, implying existence of annual seasonality in $P$. indicus catch. Two outliers of $P$. indicus catch in June 2003 and May 2011 were also estimated in the model.

\section{Discussion}

In Chilika, shrimp catches play major role in stabilising livelihoods of majority of the fishermen fishing in the lake. Large variation observed in the monthly shrimp catch in the Chilika Lagoon, could be due to indirect influence of salinity and temperature. Salinity and temperature varies seasonally and provide favourable environment for assemblage of shrimps in the lagoon. Seasonal and spatial environmental variation both directly or indirectly influences the fish species assemblage within the lagoon system. Seasonal differences in fish assemblage composition have been studied in estuaries (Balber and Balber, 1980; Elliot et al., 1990; Morin

Table 2. Best filled ARIMAX model parameter estimates and their significance for $P$. indicus catch in Chilika for the period 2001-2015

\begin{tabular}{llll}
\hline Model parameter & Estimate & Std. Error & p value \\
\hline Intercept & 20.21 & 73.83 & 0.78 \\
Autoregressive, Lag 1 & 0.80 & 0.08 & $<.0001$ \\
Autoregressive, Lag 2 & -0.30 & 0.08 & $<.0002$ \\
Seasonal autoregressive, Lag 12 & 0.44 & 0.07 & $<.0001$ \\
Salinity & 3.64 & 1.71 & 0.03 \\
Temperature & 0.74 & 2.48 & 0.76 \\
R-square & 0.75 & & \\
AIC & 1364.9 & & \\
Mean absolute \% error & 379.79 & & \\
\hline
\end{tabular}

et al., 1992) and spatial trend within estuaries have been studied by Elliott and Taylor (1989) and Pomfret et al. (1991). Among several water quality parameters, salinity to a greater extent and water temperature to lesser extent influence distribution of various penaeid shrimps (Walsh and Mitchell, 1998) and fish assemblages in estuaries (Marshall and Elliott, 1998). The trend in shrimp catch of Chilika follows seasonal hike instead of a uniform or stable catch pattern. Such trend is directly associated with the migratory behaviour of the species, as this marine species follow a strong migration pattern like other penaeid shrimps usually do. The monthly catch pattern of the species is also reflected in commercial fishery of Chilika. Annual production of $P$. indicus from the lake is nearly $1500 \mathrm{t}$ (2010-11 to 2015-16), which is more than $10 \%$ of the total commercial fish catch from Chilika. A large monthly variation in catch of $P$. indicus was found during the study period, which shows the dynamic catch pattern in the lagoon.

As part of its life cycle, juveniles of $P$. indicus enters into Chilika from the Bay of Bengal during March-April (Bhatta and Panda, 2008). It continues every year along with other penaeid shrimps. As a consequence, its annual cycles are also observed around 12 months estimated in Cycle-1 (Fig. 2). The whole life cycle more or less depends upon the salinity variability in the ecosystem and as a result, estuarine ecosystem plays a major role. In general, $P$. indicus spawns in the deeper marine waters at depths of over 7 to $37 \mathrm{~m}$ (Hall, 1962; FAO, 1985) and the post-larvae move towards shorelines and enters estuaries during nursery phase (FAO, 1980). Post-larvae of $P$. indicus prefer the estuarine nature of Chilika for nursery purpose which also acts as a potential nursery ground for several other penaeid shrimp species (Bhatta and Panda, 2008).

Salinity plays a major role in the habitat and behaviour of $P$. indicus throughout its life stages. Although the species tolerates a wide range of salinity ranging from 5 to 50 ppt (Branford, 1981; Macia, 2004), particularly in the juvenile stage, it prefers habitat salinity of around 10-15 ppt(FAO, 1980). The mean salinity of Chilika Lagoon reaches around 15-18 ppt during summer (Mohapatra et al., 2007; Mohanty et al., 2016), which turns the estuarine water a preferable destination for juveniles. As a result, a large quantity of $P$. indicus juveniles ingresses into Chilika and stay there for at least 4-5 months until the salinity of Chilika water drops. Furthermore, water salinity of $15 \mathrm{ppt}$ is suitable for highest growth increment in P. indicus (Vijayan and Diwan, 1995). Water temperature also plays a major role in the growth and moulting of the species (Vijayan and Diwan, 1995). Vijayan and Diwan (1995) also reported that higher temperature accelerates 
growth of $P$. indicus and $31^{\circ} \mathrm{C}$ is the ideal temperature. This finding also corroborated the present findings as water temperature of Chilika gradually starts increasing from February and reaches maximum in May (Mohapatra et al., 2007). Following a similar pattern, in general, the catch also increased from March to May every year.

The significant upward trend in $P$. indicus catch revealed the probability of increasing catch in the upcoming years, if the present environmental conditions of the lagoon are conserved. Seasonal (cyclic) behaviour of $P$. indicus catch of six months and twelve months indicated two peaks in catch yearly in the lagoon. Salinity and water temperature were found to have significant influence on catch of $P$. indicus. Increased salinity directly influences the abundance of $P$. indicus fishery in the Chilika Lagoon. Water temperature also has positive correlation in catch trend of $P$. indicus Therefore the cyclic catch of this fishery as modelled with STSM and ARIMAX could be a best suitable model for prediction of catch trend and also could be extended for estimation and prediction of any other fishery of the lake/lagoon and estuary. Results of the study will be helpful in formulation of fishery management plans for the Chilika Lagoon and opens up scope for strengthening further studies in similar lines in the lagoon system.

\section{Acknowledgements}

We acknowledge the Chilika Development Authority (CDA), Bhubaneswar, Odisha for providing time series fish catch and water quality data for the present study. We are extremely thankful to the Director, ICAR-CIFRI for the facilities provided for the research work.

\section{References}

Akaike, H. 1979. A Bayesian extension of the minimum AIC procedure of autoregressive model fitting. Biometrika, 66(2): $237-242$.

Bhatta, K. S. and Panda, S. 2008. Post-hydrological changes in landings of fishery resources in Chilika Lagoon. In: Sengupta, M. and Dalwani, R. (Eds.), Proceedings of Taal 2007: The 12 ${ }^{\text {th }}$ World Lake Conference, Jaipur, India, p. 1894-1902.

Blaber, S. J. M. and Blaber, T. G. 1980. Factors affecting the distribution of juvenile estuarine and inshore fish. J. Fish. Biol., 17: 143-162. doi.org/10.1111/j.1095-8649.1980.tb0 2749.x.

Box, G. E. P. and Jenkins, G. M. 1976. Time series analysis: Forecasting and control. University of Wisconsin Madison, WI and University of Lancaster, England, p. 575.

Branford, J. R. 1981. Sediment and distribution of penaeid shrimp in the Sudanese Red Sea. Estuar. Coast. Shelf. Sci., 13: 349-354. doi.org/10.1016/S0302-3524(81)80032-1.
Bruce, H. A., Dean, M. D., Swain, R. and Cole, C. 2013. Building ARIMA and ARIMAX models for predicting longterm disability benefit application rates in the public/ private sectors, University of Southern Maine. http://www. afriheritage.org/TTT/4 Building ARIMA and ARIMAX Model.pdf.

Bruno, D. O., Barbini, S. A., Astarloa, J. M. D. D. and Martos, P. 2013. Fish abundance and distribution patterns related to environmental factors in a choked temperate coastal lagoon (Argentina). Braz. J. Oceanogr., 61: 43-53. DOI: 10.1590/ S1679-87592013000100005.

Cyrus, D. P. and McLean, S. 1996. Water temperature and the 1987 fish kill at Lake St Lucia on the South Eastern coast of Africa. S. Afr. J. Aquat. Sci., 22: 105-110.

Elliot, M. and Hemingway, K. L. 2002. Fishes in estuaries, $2^{\text {nd }}$ edn. Blackwell Science, Oxford.

Elliot, M. and Taylor, C. J. L. 1989. The structure and functioning of an estuarine / marine fish community in the Forth Estuary, Scotland. Proceedings of the 21 $1^{\text {st }}$ European Marine Biologist Symposium (Gdansk), Polish Academy of Science Institute of Oceanology, Warsaw, p. 227-240.

Elliott, M., O'Reilly, M. G. and Taylor, C. J. L. 1990. The $4^{\text {th }}$ estuary: a nursery and overwintering area for North Sea fishes. Hydrobiologia, 195: 89-103.

Erzini, K., Inejih, C. A. O. and Stobberup, K. A. 2005. An application of two techniques for the analysis of short, multivariate non-stationary time-series of Mauritanian trawl survey data. ICES J. Mar. Sci., 62: 353-359.

FAO 1980. FAO species catalogue. vol. 1., Shrimps and prawns of the world: an annotated catalogue of species of interest to fisheries, Fisheries Synopsis, 125(1) FAO, Rome.

FAO 1985. Shrimp hatchery design, operation and management. In: Kungvankij, P., Tiro, Jr. L. B., Pudadera, Jr. B. J., Potestas, I. O., Corre, K. G., Borlongan, E., Talean, G. A., Bustilo, L. F., Tech, E. T., Unggui, A. and Chua, T. E. NACA Training manual series, No. 1, Network of Aquaculture Centres in Asia, Bangkok, Thailand and the Pacific, Regional Lead Centre in the Philippines, 95 pp.

Freeman, S. and Kirkwood, G. 1995. On a structural time series method for estimating stock biomass and recruitment from catch and effort data. Fish. Res., 22: 77-98. doi.org/ 10.1016/0165-7836(94)00304-F

Galvan-Pina, V. H., Galvan-Magana, F., Abitiacardenas, L. A., Gutierrez-Sanchez, F. J. and Rodriguez-Romero, J. 2003. Seasonal structure of fish assemblages in rocky and sandy habitats in Bahía de la Paz, Mexico. Bull. Mar. Sci., 72: 19-35.

Gupta, R. A., Mandal, S. K. and Paul, S. 1991. Methodology for collection and estimation of inland fisheries statistics in India, Bulletin No. 58 (Revised). ICAR-Central Inland Capture Fisheries Research Institute, Barrackpore, West Bengal, 64 pp. 
Hall, D. N. F. 1962. Observations on the taxonomy and biology of some Indo-west Pacific Penaeidae (Crustacea, Decapoda). Fishery Publications of the Colonial Office, 17: 1-229.

Harvey, A. C. 1989. Forecasting, structural time series models and the Kalman filter. Redwood Press Limited, Melksham, Wiltshire.

Harvey, A. C. 1996. Intervention analysis with control groups. Int. Stat. Rev., 64: 313-328.

Harvey, A. C., Koopman, S. J. and Shepard, N. 2004. State space and unobserved component models - Theory and applications, Cambridge University Press, Cambridge.

Isla, F. I. 1995. Coastal lagoons. In: Perillo, G. M. E. (Ed.), Geomorfology and sedimentology of estuaries, vol. 53, $1^{\text {st }}$ edn. Elsevier Science, Amsterdam, p. 241-272.

Jhingran, V. G. 1963. Report on the fisheries of the Chilika Lake 1957-1960. Bulletin No. 1, ICAR-Central Inland Fisheries Research Institute, Barrackpore, Kolkata, India.

Jhingran, V. G. and Natarajan, A. V. 1969. A study of the fisheries and fish population of the Chilika Lake during the period 1957-65. J. Inland Fish. Soc. India, 1: 49-126.

Macia, A. 2004. Juvenile penaeid shrimp density, spatial distribution and size composition in four adjacent habitats within a mangrove-fringed bay on Inhaca Island, Mozambique, Western Indian Ocean. J. Mar. Sci., 3: 163-178.

Mangla, B. 1989. Chilika Lake: Desilting Asia's largest brackishwater lagoon. Ambio, 18: 298-299.

Marshall, S. and Elliot, M. 1998. Environmental influence on fish assemblage of the Humber Estuary, U. K. Estuar. Coast. Shelf. Sci., 46: 175-184. doi.org/10.1006/ecss.1997.0268.

Meinhold, R. J. and Singpurwalla, N. D. 1983. Understanding the Kalman Filter. The American Statistician, 37: 123-127. DOI: $10.1080 / 00031305.1983 .10482723$.

Mohamed, K. H. 1969. Genus Penaeus Fabricius 1798: Penaeus indicus (H. Milne-Edwards, 1837). Bull. Cent. Mar. Fish. Res. Inst., 14: 49-64.

Mohanty, B., Muduli, P. R., Behera, A. T., Mahapatro, D., Barik, S. K., Nag, S. K., Samal, R. N. and Pattnaik, A. K. 2016. Assessment of petroleum hydrocarbon in a tropical brackishwater lagoon: Chilika, India. Chemistry and Ecology, 32: 653-668. doi.org/10.1080/02757540.2016.1 177521.

Mohanty, S. K., Bhatta, K. S., Mohanty, R. K., Mishra, S., Mohapatra, A. and Pattnaik, A. K. 2008. Eco-restoration impact on fishery biodiversity and population structure in Chilika Lake. In: Mohanty, P. K. (Ed.), Monitoring and modelling lakes and coastal Environments, Springer, Dordrecht.

Mohanty, S. K., Mishra, S. S., Khan, M., Mohanty, R. K., Mohapatra, A. and Pattnaik, A. K. 2015. Ichthyofaunal diversity of Chilika Lake, Odisha, India: an inventory, assessment of biodiversity status and comprehensive systematic checklist (1916-2014). Check List, 11(6): 1817. doi.org/10.15560/11.6.1817.

Mohapatra, A., Mohanty, R. K., Mohanty, S. K., Bhatta, K. S. and Das, N. R. 2007. Fisheries enhancement and biodiversity assessment of fish, prawn and mud crab in Chilika Lagoon through hydrological intervention. Wetl. Ecol. Manag., 15: 229-251. DOI: 10.1007/s11273-006-9025-3.

Mohapatra, A., Mohanty, S. K. and Mishra, S. S. 2015. Fish and shellfish fauna of Chilika Lagoon: An updated checklist. In: Venkataraman, K. and Sivaperuman, C. (Eds.), Marine faunal diversity in India. Elsevier Inc. Publications, p. 195-224.

Morin, B., Hudon, C. and Whoriskey, F. G. 1992. Environmental influences on seasonal distribution of coastal and estuarine fish assemblages at Wemindji, eastern James Bay. Env. Biol. Fish., 35: 219-229. DOI: 10.1007/BF00001887.

Plavan, A. A., Passadore, C. and Gimenez, L. 2010. Fish assemblage in a temperate estuary on the Uruguayan coast: seasonal variation and environmental influence. Braz. J. Oceanog., 58(4): 299-314. doi.org/10.1590/S1679-8759 2010000400005.

Pombo, L., Elliot, M. and Rebelo, J. E. 2005. Environmental influences on fish assemblage distribution of an estuarine coastal lagoon, Ria de Aveiro (Portugal). Scientia Marina, 69: 43-159. doi.org/10.3989/scimar.2005.69n1143.

Pomfret, J. R., Elliot, M., Reilly, M. G. O. and Philips, S. 1991. Special and temporal patterns in the fish communities in the U. K. North Sea estuaries. In: Elliot, M. and Ducrotoy, J. P. (Eds.), Estuaries and coast: special and temporal intercomparisons. Olsen and Olsen, Fredenborg, p. $2077-284$

Rao, A. V. P. 1967. Some observation on the biology of Penaeus indicus H. Milne Edwards and Penaeus monodon Fabricius from Chilika Lake. Indian J. Fish., 14: 251-270.

Schwartz, G. 1978. Estimating the dimension of a model. Annals of Statistics, 6: 461-464. DOI: 10.1214/aos/1176344136.

Selleslagh, J. and Amara, R. 2008. Environmental factors structuring fish composition and assemblages in a small macrotidal estuary (eastern English Channel). Estuar. Coast. Shelf Sci., 79: 507-517. DOI: 10.1016/j. ecss.2008.05.006

Stergiou, K. I. 1991. Short-term fisheries forecasting: comparison of smoothing, ARIMA and regression techniques. J. Appl. Ichthyol., 7: 193-204. doi.org/10.1111/j.1439-0426.1991. tb00597.x.

Subrahmanyam, M. 1967. Fluctuations in the prawn landings in Chilka Lake. Proceedings of the Indo-Pacific Fisheries Council, 12: 202-209.

Vijayan, K. K. and Diwan, A. D. 1995. Influence of temperature, salinity, $\mathrm{pH}$ and light on molting and growth in the Indian white prawn Penaeus indicus (Crustacea: Decapoda: 
Penaeidae) under laboratory conditions. Asian Fish. Sci., 8: 63-72.

Walsh, C. J. and Mitchell, B. D. 1998. Factors associated with variations in the abundance of epifaunal caridian shrimps between and within seagrass meadows. Mar. Freshw. Res., 49: 769-777.

World Bank 2005. Scenario assessment of provision of environmental flows to Lake Chilika from Naraj Barrage, Orissa, India. Reports from the environmental flows window of the bank Netherlands water partnership programme (World Bank) to the Government of Orissa, India, $40 \mathrm{pp}$.

Zuur, A. F. and Pierce, G. L. 2004. Common trends in northeast Atlantic squid time series. J. Sea Res., 52: 57-72. DOI: 10.1016/j.seares.2003.08.008.

Zuur, A. F., Tuck, I. D. and Bailey, N. 2003. Dynamic factor analysis to estimate common trends in fisheries time series. Can. J. Fish. Aquat. Sci., 60: 542-552. doi.org/10.1139/ f03-030. 